\title{
IMPACTS OF SEASONAL LIVESTOCK GRAZING ON PLANT COMMUNITY FEATURES: A CASE STUDY ON GRAZING PASTURES AT SONAMARGAREA IN KASHMIR HIMALAYA
}

\author{
F. A. Mir ${ }^{1}$, G. A. Bhat, B. A. Sheer, A. G. Khan
}

\begin{abstract}
The main objective of the study was todescribe the seasonal dynamics in some phytosociological attributes of dominant plant species under uncontrolled livestock grazing at three sites of Sonamarg area in Kashmir Himalaya.Vegetation was tested for A/F ratio and distribution pattern was assigned as regular (0.025), random (0.025-0.05) and contagious (> 0.05). Frequency, abundance, density andimportance value index(IVI) were also calculated to observe dominant species. Raunkaier's law of percentage frequencies was introduced to find the composition of plant community and changes thereafter brought by seasonal livestock grazing under uncontrolled stocking density. Bothriocloa pertusa, Poa annua, Sambus whightiana, Stipa siberica, Cyanodon dactylon were the dominant plant species at all the three sites. IVI values of these species were increased after experiencing peak grazing season showing their resistance to grazing. Distribution pattern also changed from contagious to random as evident from $\mathrm{A} / \mathrm{F}$ ratio. Vegetation composition also showed a tendency from homogenity to heterogenity after grazing period. Stocking density was also recorded. It was maximum for Sonamarg main site (121.50 animal units per hectare during peak seasonal grazing) followed by Baltal site (86 animal units per hectare) in the month of September and minimum for Thajiwas site (24 animal units per hectare) in October. Stocking density showed a close relationshipwith the change in number of palatable plant species and consequent change in ratio of palatable to non palatable plant species.
\end{abstract}

Key words: Grazing, Sonamarg, phyto-sociological attribute, pasture, quadrant, stocking density.

\section{INTRODUCTION}

In $19^{\text {th }}$ century, grazing techniques were and previous experience of individual animal virtually non-existent. Pastures were (Frost and Lauchbaugh, 2003). Goats prefer grazed for long periods of time with no browse (woody plants), sheep prefer forbs and rest in between. These malpractices lead to cattle prefer grasses. Cattle have been referred overgrazing and proved detrimental to land, to as generalists eating a wide variety of foods wildlife, biodiversity and livestock producers and continue even today like in current case. Buttoday ranchers have developed grazing systems to help improve the forage production for livestock, while still being beneficial to the land. Livestock animals are selective in grazing behavior. Infestation density, growth stage and availability of other feeds also influence an animal's grazing behavior (Olson, 1999). Grazing behavior can vary widely among specie, breed, age, sex, body condition, hunger and plant species. However, studies have indicated that they preferably select the grass, feed groups unless the availability of grasses is so marginal as to severely limit daily intake requirements (Frost and Lauchbaugh, 2003). Therefore, the grazing value of a plant depends on the animal species in question. Mechanical deterrents including spines on leaves and stem and other epidermal characteristics directly influence the palatability.Studies also supports the fact that the association of palatable 
species with less or non palatable species may also influence the frequency and intensity of plant defoliation.

Grazing can be regarded as an important tool for livestock production. However, when it is not properly managed, often becomes a problem. Grazing generally impacts the ecosystem, disrupting both physical characteristics and the surrounding species population and can lead to decreased forage yield, which correlates to lower quality forage. In addition, loss of ground cover by grazing causes the top soil to be more susceptible to erosion and increased weed production. By utilizing controlled grazing system, livestock production has a potential to be maximized and grazing animals act as natural fertilizing agencies to soil.

On grazed landscapes, it is often difficult to assess the extent to which herbivory influences ecosystem processes relative to biotic factors (McNaughton, 1983).The impact of livestock grazing on ecosystem varies in relation to evolutionary history of the site and the level of grazing pressure (Milchunas et al., 1988). Grazing induced modifications in species composition have been documented in numerous grass land studies throughout the world. Grazing alters composition and quantity of ground cover vegetation by removal of herbal composition and exposure of mineral soil by livestock. Long term cattle grazing have been shown to decrease the abundance of perennial grasses and forbs and increase the amount of annual grasses and weeds in western deserts (Schmuntz et al., 1967). Cattle grazing have been shown to decrease species richness and evenness in arid communities (Schmuntz et al, 1967).

The main objectives of the study were to workout, species composition, seasonal dynamicsinsomephyto-sociological attributes, distribution pattern, relative dominance of dominant plant species and changes thereafter brought by seasonal livestock grazing under uncontrolled stocking density of Sonamarg area in Kashmir Himalaya.

\section{MATERIALS AND METHODS}

\section{Measurement of Plant community features}

Phyto-sociological attributes of plant community of grazing pastures of Sonamarg area at three different sites were studied by Quadrant Method $(1 \times 1$ metre). In creeping plants, one erect shoot having functional roots were counted as 1 plant unit. Vegetation was analyzed for Density, Frequency, Abundance, importance value index (IVI) according to Curtis and McIntosh, 1950.On the basis of percentage frequency, various species were then distributed into 5 frequency classes according to Raunkaier's law of percentage frequencies. Frequency diagram of various species was checked for validation of Raunkaier's law of frequency classes to find out whether vegetation at the site was homogenous or heterogeneous. Importance Value Index was observed in order to get the relative dominance of species. The ratio of abundance to frequency (A/F ratio) was also observed to interpret the distribution pattern of species (Whitford, 1949) and distribution pattern as regular (0.025), random (0.0250.05 ) and contagious $(>0.05)$ (Curtis and Cottam, 1956).The identification of plant species was done in Center of Plant Taxonomy (COPT),University of Kashmir, Srinagar $(\mathrm{J} \& \mathrm{~K})$.

\section{Measurement of the stocking density}

Stocking density at different sites was calculated on spatio-temporal basis. Stocking density was calculated as number of animal units per hectare. Following conversion factors were applied for calculating number of animal units (AU) (Department of Forest, Govt. of Jammu and Kashmir). 


\begin{tabular}{|c|c|c|c|}
\hline $\begin{array}{l}1 \text { Cattle } \\
\text { (ox / cow) }\end{array}$ & $1 \mathrm{AU}$ & $\begin{array}{l}1 \text { Calf } \\
\text { (<1year) }\end{array}$ & $1 / 2 \mathrm{AU}$ \\
\hline 1 Horse/Pony & $1 \mathrm{AU}$ & 1 Goat & $1 / 2 \mathrm{AU}$ \\
\hline 1 Buffalo & $2 \mathrm{AU}$ & 1 Sheep & $1 / 2 \mathrm{AU}$ \\
\hline A1l Others & $1 \mathrm{AU}$ & & \\
\hline
\end{tabular}

In this study an attempt was made to asses various impacts of seasonal livestock grazing on community features of vegetation in grazing pastures of Sonamarg area in Kashmir Himalaya and a comparative analysis was worked out at three different sites of study area namely Sonamarg $\left(34^{\circ} 18^{\prime} \mathrm{N}-75^{\circ} 15^{\prime}\right.$ E), Thajiwas $\left(34^{\circ} 17^{\prime} \mathrm{N}-75^{\circ} 12^{\prime} \mathrm{E}\right)$ and Baltal $\left(34^{\circ} 15^{\prime} \mathrm{N}-74^{\circ} 24^{\prime} \mathrm{E}\right)$. All the three sites are in catchment area of Sindh River.Average annual rain fall in Kashmir ranges between $500-700 \mathrm{~mm}$ of which $40 \%$ is in the form of snow. Sonamarg area falls in the Sindh Forest Division and posses a sizable area under the pastures mostly in the alpine and sub-alpine regions.

\section{RESULTS}

The number of reported plant species at two sites, Sonamarg and Baltal decreased from 15 and 19 to 10 and 13 respectively, thereby decreasing the ratio of palatable to unpalatable species depicting clearly the resistance of some abnoxious plant species towards grazing, and forage selection of grazing animals. Thaji was which was managed (wildlife sanctuary) showed no such decrease in the number of reported plant species. According to Raunkaier's law of percentage frequencies all three sites were having homogenity in vegetation cover before grazing period, because the most of the plant species belonged to frequency class E. After grazing, the plant species belonging to frequency class $\mathrm{E}$ was decreased.
The most dominant plant species at Sonamarg and Thajiwas $^{\#}$ were Stipa siberica $\left(\mathrm{IVI}=96.91,131.28^{\#}\right), \quad$ Sambucus whightiana (IVI=94.37,104.71\#), Bothriocloa pertusa $\left(\mathrm{IVI}=79.70,89.14^{\#}\right)$ and Poa annua(IVI=73.50,79.36 ) before grazing and maintained their dominance after livestock grazing but with increased IVI value reflecting their resistance to grazing pressure. Distribution of plant species at Sonamarg site prior to grazing process were contagious $(80 \%)$, regular $(0 \%)$ and random $(20 \%)$ which changed to contagious $(60 \%)$, regular $(0 \%)$ and random $(40 \%)$ trending towards randomizing effect of grazing process (Table 01).Among 15 plant species at Thajiwas, the percentage distribution pattern remained almost same after grazing process (Table 02). Baltal site showed the dominance of Stipa siberica (IVI=112.4, 133.22*), Sambucus whightiana(IVI=97.28, 101.06*),Poa annua(IVI=71.86, 73.93*) and Cyanodon dactylon $\left(\mathrm{IVI}=66.28,77.16^{*}\right)$ and distribution patterns of plant species in whole study area were recorded as contagious $(47 \%, 54 \% *)$,random $(32 \%, 46 \% *) \quad$ and regular $(21 \%, 0 \% *)$ both before and after* peak grazing season..The recorded stocking density recorded was closely related to the results obtained for plant community features (Table 03, 04). 
Table 01. Comparison of IVI value and A/F ratio at Sonamarg before and after grazing process.

\begin{tabular}{cccccccccc}
\hline & & \multicolumn{4}{c}{ Before Grazing } & \multicolumn{3}{c}{ After Grazing } \\
\cline { 3 - 9 } S.No & Plant Sp. & $\%$ & Freq. & IVI & A/F & $\%$ & Freq. & IVI & A/F \\
& Freq. & Class & & Ratio & Freq. & Class & Ratio \\
\hline 01 & Cyanodon dactylon & 100 & $\mathrm{E}$ & 63.92 & 0.22 & 100 & $\mathrm{E}$ & 92.98 & 0.09 \\
02 & Bothriocloa pertusa & 100 & $\mathrm{E}$ & 79.70 & 0.29 & 100 & $\mathrm{E}$ & 87.66 & 0.08 \\
03 & Poa annua & 100 & $\mathrm{E}$ & 73.50 & 0.26 & 100 & $\mathrm{E}$ & 107.75 & 0.11 \\
04 & Rumex dentatus & 100 & $\mathrm{E}$ & 19.89 & 0.27 & - & - & - & - \\
05 & Oxalis acetosa & 100 & $\mathrm{E}$ & 22.8 & 0.04 & 25 & $\mathrm{~B}$ & 11.83 & 0.04 \\
06 & Taraxacum officinale & 100 & $\mathrm{E}$ & 18.85 & 0.22 & - & - & - & - \\
07 & Malva neglecta & 100 & $\mathrm{E}$ & 16.6 & 0.12 & - & - & - & - \\
08 & Trifolium pratens & 25 & $\mathrm{~B}$ & 4.84 & 0.04 & - & - & - & - \\
09 & Fragaria vesca & 50 & $\mathrm{C}$ & 12.29 & 3.03 & 25 & $\mathrm{~B}$ & 9.21 & 0.04 \\
10 & Sambucus whightiana & 100 & $\mathrm{E}$ & 94.37 & 0.36 & 100 & $\mathrm{E}$ & 101.38 & 0.21 \\
11 & Circium sp. & 100 & $\mathrm{E}$ & 6.27 & 0.04 & 25 & $\mathrm{~B}$ & 11.83 & 0.04 \\
12 & Stipa siberica & 100 & $\mathrm{E}$ & 96.91 & 0.37 & 100 & $\mathrm{E}$ & 114.95 & 0.25 \\
13 & Urtica dioeca & 100 & $\mathrm{E}$ & 43.07 & 0.11 & 100 & $\mathrm{E}$ & 65.39 & 0.11 \\
14 & Rumex nepalensis & 100 & $\mathrm{E}$ & 40.51 & 0.10 & 25 & $\mathrm{~B}$ & 9.21 & 0.04 \\
15 & Marrubium vulgare & 25 & $\mathrm{~B}$ & 7.54 & 0.08 & - & - & - & - \\
\hline
\end{tabular}

Table 02. Comparison of IVI value and $\mathrm{A} / \mathrm{F}$ ratio at Thajiwas before and after grazing process.

\begin{tabular}{|c|c|c|c|c|c|c|c|c|c|}
\hline \multirow[b]{2}{*}{ S.No } & \multirow[b]{2}{*}{ Plant Sp. } & \multicolumn{4}{|c|}{ Before Grazing } & \multicolumn{4}{|c|}{ After Grazing } \\
\hline & & $\%$ Freq & $\begin{array}{l}\text { Freq. } \\
\text { Class }\end{array}$ & IVI & $\begin{array}{c}\text { A/F } \\
\text { Ratio }\end{array}$ & $\begin{array}{c}\% \\
\text { Freq }\end{array}$ & $\begin{array}{l}\text { Freq } \\
\text { Class }\end{array}$ & $I V I$ & $\begin{array}{c}\text { A/F } \\
\text { Ratio }\end{array}$ \\
\hline 01 & Cyanodon dactylon & 100 & $\mathrm{E}$ & 77.19 & 0.26 & 100 & $\mathrm{E}$ & 82.34 & 0.21 \\
\hline 02 & Bothriocloa pertusa & 100 & $\mathrm{E}$ & 89.14 & 0.32 & 100 & $\mathrm{E}$ & 91.32 & 0.25 \\
\hline 03 & Pоа аппиа & 100 & $\mathrm{E}$ & 79.36 & 0.27 & 100 & $\mathrm{E}$ & 84.11 & 0.27 \\
\hline 04 & Rumex dentatus & 50 & $\mathrm{C}$ & 11.95 & 0.03 & 50 & $\mathrm{C}$ & 13.16 & 0.02 \\
\hline 05 & Oxalis acetosa & 100 & $\mathrm{E}$ & 25.01 & 0.02 & 50 & $\mathrm{C}$ & 14.19 & 0.03 \\
\hline 06 & Taraxacum officinale & 50 & $\mathrm{C}$ & 11.11 & 0.02 & 25 & B & 7.25 & 0.04 \\
\hline 07 & Malva neglecta & 25 & B & 6.10 & 0.04 & 25 & B & 7.25 & 0.04 \\
\hline 08 & Fragaria vesca & 25 & B & 7.56 & 0.04 & 25 & B & 9.56 & 0.04 \\
\hline 09 & Sambucus whightiana & 100 & $\mathrm{E}$ & 104.71 & 0.37 & 100 & $\mathrm{E}$ & 112.21 & 0.07 \\
\hline 10 & Circium sp. & 50 & $\mathrm{C}$ & 14.06 & 0.02 & 25 & B & 10.99 & 0.08 \\
\hline 11 & Stipa siberica & 100 & $\mathrm{E}$ & 131.28 & 0.50 & 100 & $\mathrm{E}$ & 128.15 & 0.25 \\
\hline 12 & Urtica dioeca & 75 & $\mathrm{D}$ & 24.30 & 0.04 & 75 & $\mathrm{D}$ & 26.03 & 0.01 \\
\hline 13 & Iris ensata & 50 & $\mathrm{C}$ & 18.03 & 0.07 & 25 & $\mathrm{~B}$ & 10.99 & 0.08 \\
\hline
\end{tabular}


Table 03. Comparison of IVI value and $\mathrm{A} / \mathrm{F}$ ratio at Baltal before and after grazing

\begin{tabular}{|c|c|c|c|c|c|c|c|c|c|}
\hline \multirow[b]{2}{*}{ S.No } & \multirow[b]{2}{*}{ Plant $S p$. } & \multicolumn{4}{|c|}{ Before Grazing } & \multicolumn{4}{|c|}{ After Grazing } \\
\hline & & $\begin{array}{c}\% \\
\text { Freq. }\end{array}$ & $\begin{array}{l}\text { Freq. } \\
\text { Class }\end{array}$ & IVI & $\begin{array}{c}A / F \\
\text { Ratio }\end{array}$ & $\begin{array}{c}\% \\
\text { Freq. }\end{array}$ & $\begin{array}{l}\text { Freq. } \\
\text { Class }\end{array}$ & $I V I$ & $\begin{array}{l}\text { A/F } \\
\text { Ratio }\end{array}$ \\
\hline 01 & Cyanodon dactylon & 100 & E & 66.28 & 0.33 & 100 & $\mathrm{E}$ & 77.16 & 0.33 \\
\hline 02 & Bothriocloa pertusa & 100 & E & 62.30 & 0.31 & 100 & E & 66.11 & 0.27 \\
\hline 03 & Роа аппиа & 100 & E & 71.86 & 0.37 & 100 & E & 73.93 & 0.31 \\
\hline 04 & Rumex dentatus & 100 & E & 24.84 & 0.07 & 75 & $\mathrm{D}$ & 21.63 & 0.08 \\
\hline 05 & Oxalis acetosa & 100 & E & 25.54 & 0.08 & 100 & E & 29.33 & 0.07 \\
\hline 06 & Taraxacum officinale & 100 & E & 15.68 & 0.02 & 75 & $\mathrm{D}$ & 16.27 & 0.03 \\
\hline 07 & Malva neglecta & 100 & E & 15.68 & 0.02 & 75 & $\mathrm{D}$ & 16.27 & 0.03 \\
\hline 08 & Trifolium pratens & 100 & E & 17.28 & 0.03 & - & - & - & - \\
\hline 09 & Iris ensata & 50 & $\mathrm{C}$ & 07.44 & 0.08 & 25 & B & 5.77 & 0.04 \\
\hline 10 & Capra falcaneri & 75 & $\mathrm{D}$ & 09.41 & 0.01 & 75 & $\mathrm{D}$ & 8.22 & 0.02 \\
\hline 11 & Fragaria vesca & 100 & $\mathrm{E}$ & 12.66 & 0.01 & - & - & - & - \\
\hline 12 & Marubium vulgare & 50 & $\mathrm{C}$ & 06.27 & 0.02 & - & - & - & - \\
\hline 13 & Sambucus whightiana & 100 & E & 97.28 & 1.63 & 100 & E & 101.06 & 1.15 \\
\hline 14 & Stipa siberica & 100 & E & 112.4 & 1.92 & 100 & $\mathrm{E}$ & 133.2 & 1.16 \\
\hline 15 & Rumex nepalensis & 100 & E & 18.53 & 0.13 & 75 & $\mathrm{D}$ & 9.43 & 0.05 \\
\hline 16 & Nepeta $s p$ & 100 & E & 12.40 & 0.01 & - & - & - & - \\
\hline 17 & Urtica dioeca & 100 & E & 13.85 & 0.04 & 100 & E & 24.69 & 0.05 \\
\hline 18 & Aquilegia sp. & 50 & $\mathrm{C}$ & 06.27 & 0.02 & - & - & - & - \\
\hline 19 & Polygonum $s p$. & 25 & B & 03.26 & 0.04 & - & - & - & - \\
\hline
\end{tabular}

Table 04. Average Stocking Density (SD) recorded during the study period (AU/Hactare)

\begin{tabular}{cccc}
\hline Site & $\begin{array}{c}\text { Before Grazing } \\
\text { Season }\end{array}$ & $\begin{array}{c}\text { During Grazing } \\
\text { Season }\end{array}$ & $\begin{array}{c}\text { After Grazing } \\
\text { Season }\end{array}$ \\
\hline Sonamarg & 55.50 & 121.50 & 30 \\
Thajiwas & 46.50 & 56.50 & 24 \\
Baltal & 24 & 86 & 24.50 \\
\hline
\end{tabular}

\section{DISCUSSIONS}

Grazing animals affect the performances of plants directly and indirectly. Direct impacts of grazing, which were associated with alteration in plant composition.Plant physiology and morphology resulted from defoliation and trampling by grazers. The indirect impacts stimulate plant responses to defoliation in many ways which were not readily simulated by clipping experiments.Plant community at all the three sites was analyzed before and after peak grazing season for various parameters necessary to describe a plant community.
This spatial cum temporal analysis depicted a considerable change in the composition of plant species due to the grazing pressure and also loss of vegetation cover.Vegetation at all the three sites was observed to be of contagious distribution, because $\mathrm{A} / \mathrm{F}$ ratio of maximum species was 0.05 and was homogeneous as reflected from their frequently class which they were occupying. At Sonamarg main site and Baltal site, the number of plant species declined overtime, mainly of palatable species due to the selective grazing behavior 
of livestock animal thereby decreasing the ratio of palatable to non-palatable. IVI values of non-palatable species were observed to be increased after grazing reflecting their resistance to grazing pressure. These was no change in number of plant species observed at Thajiwas overtime due to the fact that it is a managed site and away from the main route of nomadic livestock herds. Maximum stocking density was recorded at Sonamarg during the peak grazing season due to the fact that it is a camping site for local and nomadic tribes. The relative dominance of Stipa siberica, Sambucus whightiana, Poa annua, Cyanodon dactylon, Bothriocloa pertusa was observed to be more than other plant species at all the three sites of Sonamarg area, as reflected by their IVI values. Maximum decline in the number of species was observed at Sonamarg main site due to high stocking density.

The ratio of unpalatable to palatable species increases with increasing grazing severity in many rangeland systems. Any significant grazing induced change in cover, densities (or) relative abundances of certain plant species can in turn have profound implications at the community level, as these changes can translate into major conversions of community organization, for example, transforming grassland to desert (Schlesinger et al., 1990).A study that have documented shows significantly greater native plant species richness in ungrazed area as compared to those that of grazed areas (Brady et al., 1989). Lone and Pandit (2007), while assessing the importance of grazing on community features of herbal species of Langate forest division of Kashmir, reported that the growing grazing pressure not only changes natural forest ecosystem but also reduces the rich biodiversity and productivity of consistent species. The authors found that the species common to both protected and unprotected areas differ in their IVI values reflecting their tolerance to grazing pressure.

But in some studies an increase in the diversity of plants with grazing has been recorded (Collins, 1987; McNaughton, 1993). This is due to the reduction in the competitive capacity of the dominant species and the appearance of bare areas that can be occupied by other species. Livestock also contribute to increase the plant diversity through selective grazing, the use of certain areas and unequal distribution of manure.

\section{CONCLUSION}

The pasture lands of Sonamarg carry grazing livestock far more than the carrying capacity. Pronounced depletion of palatable grass species has taken place accompanied by an invasion of unpalatable species and abnoxious weeds like; Sambucus whightiana, Iris ensata, Stipa siberica, Cirsium falconeri, etc. The pastures have started exhibiting a degraded look as a result of overgrazing. If this heavy grazing will continue, the most or all perennials may disappear and will be replaced by inferior type of annual plants. Such kind of unrestricted grazing is responsible for deterioration of pasture lands.Excessive grazing has aggravated the problem of soil erosion by reduction in the density of ground cover. Being a serious problem which causes main hurdles in the successful regeneration of forests, through which the cattle pass frequently, it has to be tackled as a socioeconomical one besides being ecologically important as well.

Therefore, it calls for the co-operation of all the stake holdersto keep a check on such uncontrolled malpractices.Also it is suggested that detailed study of all pasture lands of the area should be carried out with regard to their carrying capacity and actual incidence of grazing. The areas should be graded properly so that every site receives the best scientific treatment it needs. Pasture lands should be developed and rehabilitated or managed according to ecological principles.In order to improveand minimizethe negative impacts of 
livestock grazing, sustainable management policies with regard to grazing should be framed, executed and followed.

\section{ACKNOWLEDGEMENT}

I highly acknowledge the help of my teachers especially my supervisor Professor G A Bhat for his able guidance during the whole study period. I also thank Head of the Department, Environmental science Kashmir University, Srinagar for providing necessary facilities to carry out this study.

\section{REFERENCES}

Brady, W.W., Stromberg, M.R., Aldon, E.F., Bonham, C.D. and Henry, S.H. (1989). Response of semi desert grassland to 16years of rest from grazing.Journal of Range Management.42:284-288.

Collins, S.L.(1987). Interaction of disturbances in tallgrass prairie: A field experiment. Ecology. $68,1243-1250$.

Cottam, G., Curtis, J. T. and Hale, B. W. (1953). Some sampling characteristics of a population of randomly dispersed individuals, Ecol.34: 741-757.

Cremin, L.A., Silva, A. and Kim, A. (1983).The problematic eroded soilin belihuloya, Journal of Agricultural Sciences. 9(2): 33-40.

Curtis, J. T. andCottam, G. (1956).Plant Ecology Workbook.Laboratory Field Reference Manual.BurgressPul. Co., Minnesota. 193pp.

Curtis, J. T. andMcIntosh, R. P. (1950). The inter relations of certain analytic and synthetic phyto-sociological characters. Ecol. 31:434-455.

Frost, R.A. and Launchbaugh,K.L. (2003). Prescription Grazing for Rangeland Weed Management -- A new look at an old tool. Rangelands.25: 43-47.

Lone, H A.(2009). Ecological studies of Langate Forest Division of Kashmir. Ph. D. Thesis, University of Kashmir, Srinagar, 190006.

Lone, H. A. and Pandit, A. K. (2007).Impact of grazing on community features and biomass of herbaceous species in Langate Forest Division of Kashmir.Ind. For.133(1): 93-100.

Mcnaughton S.J. (1993). Grasses and grazers, science and management.EcolApplic 3:17-20.

Milchunas, D.G., Sala, O.E., and Lauenroth, W.K. (1988).A generalizedmodel of the effects of grazing by large herbivoreson grassland community structure.American Naturalist.132:87-106.

Naveh, Z., Whittaker, R.H. (1980). Structural and floristic diversity of shrublands and woodlands in northern Israel and other mediterranean areas. Vegetatio 41: 171-190.

Olson, B.E. (1999). Manipulating Diet Selection to Control Weeds. In: K.L. Launchbaugh, K.D. Sanders, and J.C. Mosley, eds. Grazing Behaviour of Livestock and Wildlife. Idaho Forest, Wildlife \& Range Exp. Sta. Bull.\#70 Univ. of Idaho, Moscow, ID. 
Olson, B.E.(1999). Impacts of noxious weeds on ecologic and economicsystems. In: Sheley, R.L., Petroff, J.K. (Eds.), Biology and Managementof Noxious Rangeland Weeds. OSU Press, Corvallis, Oregon.

Schlesinger, W.H., Reynolds, J.F., Cunningham, G.L., Huenneke, L.F., Jarrell, W.M., Virginia, R.A., and Whitford, W.G. 1990. Biological feedbacks in global desertification. Science.247:1043-1048.

Schmutz, E.M., Michaels, C.C., and Judd, B.I. (1967).Boysag point: arelict area on the north rim of Grand Canyon in Arizona. Journal of Range Management.20:363-369.

Whitford, P. B. 1949. Distribution of woodland plants in relation to succession and clonal growth.Ecology.30: 199-208. 